Foreign Aid Allocation, Governance, and Economic Growth 
This book is published by the University of Pennsylvania Press (UPP) on behalf of the International Food Policy Research Institute (IFPRI) as part of a joint-publication series. Books in the series present research on food security and economic development with the aim of reducing poverty and eliminating hunger and malnutrition in developing nations. They are the product of peer-reviewed IFPRI research and are selected by mutual agreement between the parties for publication under the joint IFPRI-UPP imprint. 


\section{Foreign Aid Allocation, Governance, and Economic Growth}

KAMILJON T. AKRAMOV

Published for the International Food Policy Research Institute

University of Pennsylvania Press

Philadelphia 
Copyright @ 2012 International Food Policy Research Institute

All rights reserved. Except for brief quotations used for purposes of review or scholarly citation, none of this book may be reproduced in any form by any means without written permission from the publisher.

Published by

University of Pennsylvania Press

Philadelphia, Pennsylvania 19104-4112

www.upenn.edu/pennpress

\section{Library of Congress Cataloging-in-Publication Data}

\section{Akramov, Kamil.}

Foreign aid allocation, governance, and economic growth / Kamiljon T. Akramov. — 1st ed. p. cm. - (International Food Policy Research Institute)

Includes bibliographical references and index.

ISBN 978-0-8122-4465-6 (hardcover : alk. paper)

1. Economic assistance-Developing countries-Evaluation. 2. Economic developmentSocial aspects-Developing countries. 3. Economic indicators-Developing countries.

4. Developing countries-Economic conditions. I. Title. II. Series: International Food Policy Research Institute (Series)

HC59.7.A752 2012

338.9109172'4-dc23

2012004087

Printed in the United States of America on acid-free paper 10987654321 